\title{
DINAMIKA TABARRUKAN DI PESANTREN BUNTET DESA MERTAPADA KULON KEC. ASTANAJAPURA KAB. CIREBON
}

\author{
DYNAMICS OF TABARRUKAN IN THE BUNTET ISLAMIC \\ BOARDING SCHOOL IN MERTAPADA KULON VILLAGE, \\ ASTANAJAPURA, CIREBON
}

\author{
Lutfi Lutfia Lutfin \\ Institut Agama Islam Negeri Syekh Nurjati Cirebon \\ lutfinlutfia@gmail.com
}

\begin{abstract}
ABSTRAK
Penelitian ini bertujuan untuk mengetahui dinamika tabarrukan yang ada di pesantren desa Mertapada Kulon. Tabarrukan merupakan salah satu ciri khas tradisi pesantren, yang dijadikan sebagai salah satu alat untuk mempererat hubungan antar kelompok masyarakat, tabarrukan yang berada di desa ini juga merupakan bagian dari tindakan sosial. Masalah yang akan diteliti adalah: (1) Bagaimana bentuk-bentuk tabarrukan yang ada di pesantren; (2) Bagaimana dinamika tabarrukan di pesantren terjadi.

Penelitian ini dilakukan dengan menggunakan metode kualitatif deskriptif, untuk mengetahui dinamika tabarrukan yang terjadi di masyarakat pesantren. Teknik dan metode penggalian data yang digunakan ialah; pengamatan (observasi) dan wawancara mendalam (interview). Hasil data yang telah terkumpul, kemudian dideskripsikan dan dianalisa. Sedangkan, landasan teori yang digunakan adalah konsep kharisma Max Weber. Pada sisi lain, peneliti mencoba memahami bagaimana para pelaku tabarrukan memahami kondisi tradisi tabarrukan dulu dengan sekarang, kebiasaankebiasaan, norma, hubungan sosial, dan relasi yang di bentuk para pelaku tabarrukan.

Dari penelitain ini, diperoleh hasil penelitian bahwa dinamika tabarrukan yang ada di masyarakat pesantren terjadi di seluruh lapisan yang ada di masyarakat, saat ini masyarakat sudah berubah, dan mengikuti perkembangan zaman, baik itu kiai, santri, maupun masyarakat. Penyebab terjadinya perubahan tersebut karena adanya faktor internal dan faktor eksternal. Faktor internal terjadi, karena kurangnya kesadaran diri dari dalam diri masing-masing kelompok yang saat ini disibukkan dengan aktivitas dan kesibukannya sendiri. Sedangkan faktor eksternal terjadi, karena masyarakat kini telah mengikuti perkembangan zaman yang semakin maju, dan banyaknya budaya luar yang masuk melalui perkembangan zaman, pernikahan, maupun pendidikan yang dapat merubah pola pikir serta kebiasaan masyarakat. Dulu, pesantren dan kiai dijadikan sebagai kiblat untuk masyarakat belajar, dan memahami aktivitas sehari-hari, baik aktivitas sosial maupun aktivitas agama. Norma dan pola kehidupan yang ada di masyarakat dulu sangat bergantung pada apa yang diajarkan di pesantren. Berbeda dengan sekarang, norma dan pola kehidupan masyarakat sangat bergantung pada kecerdasan, dan kesadaran masyarakat itu sendiri, baik dalam mengolah maupun memandang setiap dan dan informasi.
\end{abstract}

Kata Kunci: Dinamika, Tabarrukan, Masyarakat Pesantren 
Jurnal Yaqzhan : Analisis Filsafat, Agama dan Kemanusiaan|

Vol 5, No 1, Juni 2019

\begin{abstract}
This study aims to determine the dynamics of tabarrukan in the Islamic boarding school in Mertapada Kulon village. Tabarrukan is one of the characteristics of a traditional Islamic boarding school, which is used as a tool to strengthen relations between community groups, tabarrukan in this village is part of social action. The problems that will be examined are: (1) How are the forms of tabarrukan in the boarding school; (2) How does the dynamics of tabarrukan occur in boarding schools.

This research was conducted using qualitative descriptive methods, to determine the dynamics of tabarrukan that occur in the boarding school community. The techniques and methods of extracting data used are; observation (observation) and in-depth interviews (interviews). The results of the data collected will be described and analyzed. Meanwhile, the theoretical foundation used is the concept of charisma Max Weber. On the other hand, researchers try to understand how the perpetrators of tabarrukan understand the conditions of the traditional tabarrukan with now, habits, norms, social relations, and relations in the form of the perpetrators of tabarrukan.

From this research, the results of the research show that the dynamics of tabarrukan in the pesantren community occur in all layers of society, now that the community has changed, they are following the times, both kiai, santri, and society. The cause of the change is due to internal factors and external factors. Internal factors occur, because of the lack of selfawareness from within each group which is currently preoccupied with their own activities and activities. While external factors occur, because the community has now followed the development of an increasingly advanced era, and the many external cultures that enter through the development of time, marriage, and education that can change people's mindsets and habits. In the past, Islamic boarding schools and clerics were used as a mecca for the learning community, and understood daily activities, both social activities and religious activities. The norms and patterns of life that exist in society used to depend on what is taught in Islamic boarding schools. In contrast to the present, the norms and patterns of people's lives are very dependent on intelligence, and the awareness of the community itself, both in processing and looking at every and and information.
\end{abstract}

Keywords: Dynamics, Tabarrukan, Society of Islamic Boarding School 


\section{PENDAHULUAN}

Tabarrukan atau tradisi ngalap berkah merupakan salah satu tradisi yang menjadi ciri khas dari pesantren. Tabarrukan juga termasuk bagian dari tindakan sosial yang telah ada sejak dulu dan disakralkan oleh masyarakat pesantren. Di Cirebon sendiri, tradisi ini masih memiliki banyak peminat. Hal itu terbukti dengan masih ramainya kunjungan ke situs-situs seperti makam para wali dan kiai yang ada di Cirebon. Selain mengunjungi situs-situs keramat seperti makam, tabarrukan juga banyak dilakukan oleh masyarakat yang tinggal di kawasan pesantren. Salah satu kawasan pesantren di wilayah Cirebon ini terletak di Desa Mertapada Kulon Kec. Astanajapura. Pesantren di desa ini lebih dikenal dengan sebutan Pesantren Buntet Cirebon.

Pesantren Buntet termasuk yang terbesar di Cirebon. Usianya pun terbilang tua, yang didirikan oleh tokoh ulama besar pada tahun 1750an. Pesantren Buntet Cirebon sebetulnya lebih cocok dikatakan sebagai lingkungan pesantren, bukan nama sebuah lembaga atau pondok pesantren. Dimana di dalamnya terdapat banyak pondok pesantren yang diatasnamakan berbeda. Sebutan Pesantren Buntet sendiri lebih mengarah ke kawasan bahwa di lingkungan tersebut banyak dihuni pondok pesantren yang diasuh oleh Kiai yang berbeda pula.

Lingkungan pesantren sendiri dibangun oleh beberapa unsur dasar, diantaranya ialah Kiai, masjid atau musholah, asrama, santri dan kitab kuning. Unsur Kiai mempunyai peran sentral terhadap arah dan kehidupan pondok pesantren sebagai pengampu kitab kuning yang menjadi kurikulum pendidikan sekaligus sebagai imam shalat di masjid atau musholah. Kehidupan dipesantren tidak bisa lepas dari tradisi-tradisi yang ada dan tradisi yang ada dilingkungan pesantren sangat beragam, diantaranya adalah tradisi membaca kitab kuning, menghafal nadzoman, ziarah, khotmil qur'an, dan tabarrukan.

Sejak awal perkembangannya, pesantren tumbuh dari bawah atas kehendak masyarakat yang terdiri dari Kiai, santri dan masyarakat sekitar.

\footnotetext{
${ }^{1}$ Zamakhsyari Dhoefir, Tradisi Pesantren Studi Tentang Pandangan Hidup
}

Kiai,Jakarta: LP3ES,1982,hlm.45-55 
Dalam hal ini, peran Kiai paling dominan, sedangkan masyarakat dan santri hanya berperan dalam mendukung dan mengembangkan pesantren. Aspek dasar yang ada di pesantren adalah otonomi. Kiai menjadi penguasa tunggal di pondok pesantren.

Pesantren merupakan lembaga subkultur dengan banyak fenomena sosial. Hal tersebut bisa dilihat dari cara hidup, pandangan hidup dan tata nilai yang di yakini, maupun hirarki kekuasaan intern tersendiri yang ditaati. Pesantren dapat berfungsi sebagai media yang memunculkan dinamika masyarakat yang ada disekitarnya. Kedudukan pesantren yang khas di tengah-tengah masyarakat diharapkan bisa menjadi sebuah alternatif segala hal, baik dijadikan sebagai pusat pengembangan maupun pembangunan masyarakat yang berorientasi pada nilai-nilai yang ada. ${ }^{2}$ Salah satu nilai-nilai yang di percaya adalah berkah.

${ }^{2}$ Cholilatus Sa'diyah, Pemaknaan Berkah

Dalam Pengabdian Santri di Pondok

Pesantren Nurul Huda Dusun Suci Desa

Jubellor Kecamatan Sugio Kabupaten
Berkah bagi masyarakat yang hidup di lingkungan pesantren tidak bisa dilepaskan dari kehidupan seharihari. Masyarakat meyakini bahwa berkah adalah sumber ketentraman. Berkah bisa didapatkan dengan berbagai tindakan yang sudah diyakini sejak lama dan dapat membawa kebaikan. Untuk itulah, berkah dimaknai sebagai sumber kekayaan spiritual. Bagi masyarakat pesantren, berkah seakan-akan menjadi sebuah tujuan mulia yang hendak dicapai, dimana orang yang mendapatkannya terbilang sukses dan bahagia. Dalam dunia pesantren sendiri, nilai-nilai berkah merupakan syarat utama dan akidah yang selama ini diyakini dan mengkristal pada jiwa masyarakat. Keikhlasan dan berkah adalah nilai keyakinan beribadah dengan mengarahkan seluruh perkataan, perbuatan dan jihad hanya untuk Allah dan mengharap ridha-Nya, tanpa melihat pada kekayaan dunia. ${ }^{3}$

Lamongan, Surabaya: Skripsi UIN Sunan Ampel Surabaya,2015,hlm,4 ${ }^{3}$ Zamakhyari Dhofier, Tradisi Pesantren Studi tentang Pandangan Hidup Kiai, hlm,7784 
HASIL DAN PEMBAHASAN

\section{Tabarrukan Sebagai Ciri Khas Pesantren}

Tradisi tabarrukan atau ngalap berkah lekat dengan dunia pesantren. Karena, salah satu faktor lahirnya tradisi tabbarukan adalah pesantren. Adapun nilai-nilai yang tercermin dalam tradisi tabarrukan diantaranya adalah keikhlasan, kepatuhan, dan pengabdian yang akhirnya menumbuhkan sikap kepedulian. Budaya pengabdian ini banyak dilakukan oleh masyarakat dan santri. Ketaatan dan kerelaan biasanya mereka ekspresikan dengan kesiapannya untuk bekerja di pondok pesantren. ${ }^{4}$ Tradisi tabarrukan di pesantren merupakan sebuah tradisi yang mampu menggambarkan polapola kehidupan di masyarakat, dan berlangsungnya suatu proses tata nilai, di dalamnya terdapat simbol-simbol, dan membawa sebuah daya tarik keluar yang memungkinkan masyarakat untuk menganggap bahwa

${ }^{4}$ Cholilatus Sa'diyah, Pemaknaan Berkah Dalam Pengabdian Santri di Pondok Pesantren Nurul Huda Dusun Suci Desa Jubellor Kecamatan Sugio Kabupaten Lamongan,hlm,14 pesantren merupakan sebuah jalan alternatif bagi sikap hidup masyarakat. Berkembangnya suatu proses yang berpengaruh dan mempengaruhi antara pesantren dan masyarakat, akan memunculkan sebuah puncak pembentukan nilai-nilai baru, yang secara umum dapat diterima oleh kedua belah pihak. Sebuah proses dan nilai yang terkandung akan sangat mempengaruhi aspek kehidupan masyarakat. Sehingga, kini pesantren bukan hanya sekedar lembaga pendidikan, tetapi sudah menjadi salah satu pusat pembangunan yang dapat mempengaruhi masyarakat secara keseluruhan.

Melalui proses dan nilai yang di anut, memunculkan sebuah komunikasi dan kedekatan antara satu sama lain. Tradisi tabarrukan merupakan salah satu bentuk praktik sosial yang banyak dilakukan, baik oleh masyarakat maupun santri, karena adanya tradisi ini begitu lekat dengan pesantren.

Seiring dengan perkembangan zaman, kedekatan antara masyarakat dan pesantren mulai berubah. Perubahan masyarakat ini juga akan berdampak pada pesantren dan praktik-praktik sosial yang ada. 
Perubahan dalam masyarakat bisa disebabkan karena adanya pertambahan penduduk yang membuat berubahnya ekologi, juga dapat menyebabkan berubahnya tata sosial antara hubungan kelompokkelompok sosial. Perubahan sosial juga bisa disebut sebagai konsep yang serba menyeluruh yang difokuskan pada perubahan atau fenomena sosial di berbagai kehidupan manusia dari tingkat individu hingga tingkat kelompok. 5 Adanya perubahan tersebut tentunya akan menimbulkan fenomena perubahan sikap antar kelompok sosial menjadi sebuah masalah alami dalam tatanan kemasyarakatan.

Masyarakat, menurut Muhamad Maksum merupakan pondasi paling utama bagi pesantren. Maka, agar pondasi itu tetap kokoh dan pesantren tetap dapat dikatakan eksis, perlu kiranya bagi pesantren untuk memperhatikan kebutuhan dan tuntutan masyarakat yang ada disekitarnya. Hal ini dikarenakan semakin pesatnya arus globalisasi yang meniscayakan terjadinya perubahan di segala aspek kehidupan

${ }^{5}$ Robert H Lauter, Perspektif Perubahan Sosial, Jakarta: PT. Rineka Cipta, 1993,hlm,5 sosial, termasuk perubahan orientasi, persepsi, maupun tingkat selektifitas masyarakat dalam segala hal yang berbau pesantren. ${ }^{6}$ Perubahanperubahan yang terjadi bukan hanya berdampak pada hubungan antar kelompok sosial, tetapi juga akan meberubah sikap dan praktik sosial yang dilakukan antar kelompok seperti tradisi tabarrukan.

Tabarrukan yang dulu begitu disakralkan oleh masyarakat, kini seiring berjalannya waktu, perlahan mulai luntur dan sudah tidak sesakral dulu. Perubahan tersebut terlihat sejak tahun 2000 dan semakin terlihat sekitar tahun 2006. Dengan fenomena tersebut, penulis akan membahas mengenai bentuk dan dinamika tabarrukan yang ada di pesantren Buntet. Untuk mengetahui dinamika tersebut, penulis akan menggunakan konsep kharisma dari Weber dengan metode kualitatif deskriptif.

\section{Konsep Tabarrukan Bagi Masyarakat Pesantren}

Tabarrukan atau ngalap berkah merupakan sebuah praktik sosial yang sudah tidak asing lagi

\footnotetext{
${ }^{6}$ Amin Haedari, et al. Masa Depan Pesantren, Jakarta: IRD Press, 2004, hlm, 81
} 
bagi masyarakat, karena tradisi yang telah ada sejak dulu ini begitu melekat dalam kehidupan masyarakat, khususnya masyarakat pesantren yang setiap harinya memang melakukan praktik tersebut. Harapan dari sebuah proses tabarrukan sendiri bergam, karena setiap masyarakat juga memaknainya berbeda-beda, sesuai dengan keyakinan akan keberkahan itu masing-masing.

\section{Tabarrukan merupakan} sebuah kecenderungan manusiawi yang telah ada sejak dulu. Bahkan berkah dapat dikatakan menjadi sebuah kebutuhan setiap manusia, dan tidak mengherankan jika demam ngalap berkah menjadi sebuah trend turun temurun bagi semua lapisan masyarakat. Istilah dari ngalap berkah berasal dari kata ngalap atau meminta dan berkah. Dalam Kamus Besar Bahasa Indonesia, kata ngalap berasal dari kata "alap" yang memiliki arti mengambil atau meminta (menjolok buah yang berada pada tempat yang tinggi). ${ }^{7}$

Kata berkah sendiri secara bahasa berasal dari kata barokah, yang artinya berkembang dan

${ }^{7}$ Departemen Pendidikan dan Kebudayaan, Kamus Besar Bahasa Indonesia, Jakarta: Balai pustaka,1989,hlm.20 bertambah, tetap dan terus melekat, kebahagiaan dan kemuliaan. ${ }^{8}$ Dalam bahasa Arab, susunan kalimat yang diturunkan dari kata berkah ialah lafadz tabarrik, yang berarti mendoakan seseorang atau lainnya agar mendapatkan keberkahan, tabarrak yang berarti yang disucikan atau yang di muliakan, al-barakah yang berarti banyak dalam segala kebaikan dan tabarruk yang berarti mencari berkah. ${ }^{9}$

Sedangkan berkah (barokah) secara istilah dapat juga diartikan sebagai berkembang atau bertambahnya kebaikan (ziyadahalkhair). Bentuk praktik mencari berkah (ngalap barokah) atau mencari tambahnya suatu kebaikan (thalab ziyadah al-khair) sendiri disebut dengan tabarruk. 10 Bertabarruk dengan sesuatu artinya mencari berkah dengan sebuah perantara yang dianggap membawa sebuah keberkahan.

\footnotetext{
${ }^{8}$ Al-Judai, Nashir bin Abdurrahman bin Muhammad,Tabarruk: Memburu Berkah Sepanjang Masa di Seluruh Tempat di Dunia Menurut Al-Qur'an dan As-Sunnah,Jakarta: Pustaka Imam Syafi' 'i,2009,hlm. 28-30

${ }^{9}$ Al-Judai, Nashir bin Abdurrahman bin Muhammad,hlm. 33-35

${ }^{10}$ Muhammad Idrus Ramli, Buku Pintar Debat dengan Wahabi, Surabaya:Bina Aswaja,2010,hlm,7
} 
Berkah dalam pandangan masyarakat mempunyai makna tidak hanya spiritual, tetapi juga formal dan material. Berkah dapat dibendakan, sehingga dapat dirasakan manfaatnya dan diketahui oleh orang ain yang memperhatikannya. Demikianlah sebabnya dalam konteks pembicaraan sehari-hari dapat dinyatakan, contohnya ketika orang memiliki usaha dan usaha nya berhasil, maka pandangan orang itu adalah sebuah usaha yang memperoleh berkah. Berkah dapat berupa benda (harta,pangkat, kendaraan, jodoh, anak, dan lain sebagainya). menurut konsepsi orang jawa, berkah itu berupa dunyo, turonggo lan kukil,yang artinya banyak harta, kendaraan yang bagus, dan lain sebaganya. $^{11}$

Sedangkan berkah yang bersifat spiritual menurut masyarakat merupakan suatu hal yang dapat membuat hidup menjadi lebih tenang. Masyarakat percaya dengan melakukan tabarrukan, maka hidupnya akan lebih tenang, tentram, damai, dan dapat lebih mensyukuri hidup. Rasa syukur yang menurut

\footnotetext{
${ }^{11}$ Nur Syam, Islam Pesisir, Yogyakarta: LkiS Pelangi Aksara,2005,hlm.158-159
}

mereka kadang sering terlupakan dapat selalu ingat dengan melakukan praktik ngalap barokah, karena dalam praktik ini mereka diajarkan sikap nerimo,bagaimana cara mensyukuri hidup, baik secara langsung maupun tidak langsung. ${ }^{12}$

Tabarrukan adalah sebuah bentuk kemaslahatan Ilahi yang diberikan kepada sesuatu yang dikehendaki, baik itu kepada makhluk hidup, benda ataupun ruang waktu. ${ }^{13}$ Umumnya, masyarakat memahami pengertian berkah dan tabarrukan itu sama dan hampir tidak memiliki perbedaan, bahkan masyarakat justru lebih femiliar dengan kata berkah di bandingkan dengan kata tabarrukan. Sehingga, masyarakat lebih sering menggunakan kata ngalap barokah dibandingkan dengan kata tabarrukan.

Dalam hal ini, norma, nilai dan kepercayaan merupakan hal dasar yang menjadi alasan masyarakat untuk menjalankan tabarrukan. Meskipun di luar dari hal itu sudah ada landasannya sendiri seperti Al-

\footnotetext{
${ }^{12}$ Hasil wawancara dengan $\mathrm{R}$ (orang yang telah mengabdi di pesantren selama 20 tahun menjadi tukang masak), tanggal 23-01-18, pukul 16.15 di kediaman $R$

${ }^{13}$ Hasil wawancara dengan Kang Ade (tokoh agama, sekaligus pengasuh salah satu pondok pesantren di Buntet), tanggal 27 Juli 18,
} 
qur'an dan hadist. Dalam hal ini, masyarakat menafsirkan alasan mengapa melakukan tabarrukan kepada seseorang yang dianggap suci tetaplah berbeda-beda. Masyarakat yang mesih manut cenderung berpendapat bahwa tabarrukan dilakukan karna keyakinannnya terhadap berkah dan orang yang memberikan berkah merupakan seseorang yang memiliki power full yang tidak dimiliki orang lain, selain itu pengetahuan, ilmu agama yang tinggi dan memiliki sesuatu yang tidak dimiliki orang lain juga merupakan alasannya dianggap suci dan harus dihormati. Dalam hal ini semuanya ada pada sosok seorang Kiai. Dalam tabarrukan, peran dan fungsi keyakinan sangat penting, keyakinan sendiri menurut Rokeach adalah sebuah pokok-pokok yang tetap soal pengharapan. Keyakinan merupakan asumsi dasar tentang apa yang nyata dan mungkin dan apa yang tidak. ${ }^{14}$

Berbeda dengan itu, ada juga sebagian masyarakat yang berpendapat bahwa ia sebenarnya melakukan tabarrukan bukan karena

\footnotetext{
${ }^{14}$ Abdullah Ali, Sosiologi Islam, Bogor: IPB Press, 2005,hlm.25
}

ia mengharapkan sesuatu berupa berkah. Melainkan, ia melakukan tabbarukan seperti menghormati, ataupun khidmat karena seseorang itu memang pantas untuk di hormati. ${ }^{15}$ Ia dihormati bukan karena kekuasaan atau jabatannya, melainkan karena sifat dan tingkah lakunya yang memang membuat sebagian masyarakat merasa segan kepadanya.

Pada umumnya, penghormatan dan pengagungan terhadap seorang Kiai merupakan sebuah tradisi yang diwarisi oleh masyarakat tradisional, sehingga kemudian muncullah sebuah pembelaan-pembelaan yang luar biasa dari masyarakat terutama santri terhadap keamanan seorang Kiai. ${ }^{16}$ Sikap heroik itu merupakan bagian dari bentuk bakti, khidmat, dan loyalitas yang tinggi terhadap seorang Kiai.

Pada proses tabarrukan, kepercayaan merupakan salah satu kunci untuk mendapatkannya, dan keyakinan masyarakat pesantren akan berkah sendiri begitu tinggi, sehingga

\footnotetext{
${ }^{15}$ Hasil wawancara dengan U(santri yang telah mondok selama 10 tahun), tanggal 2607-18, pukul 20.15 diwarung depan IKPB ${ }^{16}$ Ali Usman, Kiai Mengaji Santri Acungkan Jempol, Yogyakarta: Pustaka Pesantren, 20013,hlm.51
} 
membuat berkah menjadi sesuatu yang harus dikejar dan di dapat, karena dengan mendapatkannya masyarakat merasa lebih mulia dan sukses. Masyarakat merasa lebih mulia karena dengan berkah mereka percaya dapat lebih dekat dengan Allah dan merasa lebih sukses dalam menjalani hidup, karena berkah merupakan salah satu cita-cita atau tujuan hidup yang harus dicapai. Walaupun berkah merupakan sesuatu yang abstrak tetapi menurut masyarakat dapat dirasakan, dan ia percaya dengan hati yang tulus dan ikhlas mengabdi dan bekerja untuk Kiai, ia akan memperoleh sebuah berkah, baik berkah batiniah yang mampu membuat diri lebih dekat dengan sang kuasa maupun berkah badaniah yang dapat menopang hidupnya. $^{17}$

Adapun munculnya berkah salah satu sebabnya adalah karena adanya karomah. Selama ini karomah banyak dipahami sebagai satu sifat yang melekat pada diri orang suci yang mampu menjadi perantara pertolongan dari Allah kepada orang

\footnotetext{
${ }^{17}$ Hasil wawancara dengan J (santri yang telah mondok selama 7 tahun dan mengabdi di pesantren selama 3 tahun) tanggal 04-022018, pukul 15.45 bertempat di ponpes Darussalam
}

yang membutuhkannya. ${ }^{18}$ Selama ini, masyarakat pesantren percaya dan yakin bahwa Kiai merupakan sosok yang suci, memiliki karomah tertentu sehingga mampu memberikan berkah kepada siapa saja yang ingin menjalin sebuah hubungan secara positif dengan Kiai, dan hal inilah yang akhirnya memancing masyarakat untuk melakukan tabarrukan kepadanya.

Lewat karomah yang dimiliki sang Kiai hingga akhirnya Kiai dapat memberikan berkah secara tidak langusung memunculkan kharisma dari dalam diri Kiai dan hal tersebut diakui oleh masyarakat. Pandangan seperti itu diakui oleh masyarakat karena memang didukung oleh adanya faktor berupa keadaan atau kondisi masyarakat yang mempengaruhi perjalanan hidup masyarakat dalam menemukan kesesuaian mutu spiritual dan intelektualnya melalui ajaran hidup yang Kiai berikan. Dalam banyak hal, sosok seorang Kiai mempunyai daya tawar yang cukup tinggi apabila dilihat dari sejarah dan kapabilitas Kiai dalam menjawab pertanyaan atau

${ }^{18}$ Lutfi Hakim, Berkah Kiai dalam Pandangan Santri, Skripsi: STAIN Salatiga, 2007,hlm,18 
hal-hal yang ditemui selama menjalankan proses pembelajaran sekaligus pendidikan yang diajarkan kepada masyarakat. ${ }^{19}$

Pada lingkungan pesantren kepercayaan akan karomah, berkah dan syafaat yang begitu kuat ditambah wibawa dan kharisma Kiai yang mampu menjadi daya tarik tersendiri bagi masyarakat membuat pandangan bahwa Kiai adalah pewaris nabi ini semakin di percaya. Oleh karena itlah menjadi sebuah kewajiban tersendiri bagi masyarakat pesantren untuk bersikap patuh, taat dan setia kepadanya. Kiai dalam hal ini bukan hanya dijadikan sebagai sumber agama saja tetapi juga menjadi seorang perantara untuk dapat lebih dekat dengan Tuhan.

Dinamika Tabarrukan di Pesantren Buntet

\section{Pandangan Masyarakat} Pesantren Terhadap Tabarrukan Tabarrukan merupakan

sebuah tradisi Islam yang masih banyak dilakukan oleh masyarakat pesantren. Tabarrukan dalam ruang lingkup pesantren mempunyai ciri khas tersendiri. Dalam ruang lingkup

\footnotetext{
${ }^{19}$ Mark Woodward, Islam Jawa: Kesalehan Normatif Versus Kebatinan, Penerjemah Hairus Salim,

Yogyakarta:LkiS,1999,hlm.189
}

ini, biasanya objek yang digunakan dapat berupa benda, tempat, ruang waktu maupun makhluk hidup. Akan tetapi, masyarakat pesantren cenderung menjadikan seorang Kiai sebagai objek untuk dimintai berkah.Sedangkan, objek lain seperti benda-benda atau yang lainnya hanya sebagai pelengkap saja. Misalnya bertabarruk kepada makamnya seorang Kiai, ulama, dan tempattempat suci dilakukan secara tidak rutin, tetapi hanya pada waktu-waktu tertentu saja. Berbeda dengan bertabarruk kepada Kiai, yang mungkin dilakukan setiap hari secara rutin.

Bagi masyarakat pesantren, tabarrukan bukanlah sebuah kewajiban tetapi seperti wajib untuk dilakukan. Bahkan, pemahamanpemahaman atau doktrinisasi tersebut telah mendarah daging dan, masyarakat menerima itu dengan suka rela tanpa adanya paksaan. Masyarakat percaya dengan melakukan tabarrukan, akan ada hasil yang akan ia dapat.Kenyamanan, kedamaian, dan ketenangan dalam hidup merupakan gambaran dari hasil bertabarruk. 
Tabarrukan atau meraih yang dipakai oleh orang shaleh) berkah melalui orang suci seperti wali, diantaranya ialah:

Kiai dan sebagainya sudah menjadi hal yang biasa terjadi di masyarakat pesantren. Kepercayaan akan hal tersebut lebih banyak di pengaruhi oleh alam pikiran dan hal-hal yang yang berbau religius-magis, yang jika tidak berhati-hati dalam melakukannya bisa mencederai tauhid kepada Allah.

Dari hasil observasi dan wawancara di lapangan yang penulis temukan, bahwasannya masyarakat pesantren baik itu masyarakat lokal maupun santri memandang berkah sebagai sesuatu yang diyakini menjadi bertambahnya kebaikan (ziyadatul khoir), dalam arti pengaruh berkah itu muncul dan tumbuh dari keyakinan yang ada di dalam diri masyarakat pesantren sendiri.

\section{Bentuk-Bentuk Tabarrukan}

Dalam pembahasan ini, tabarrukan dapat bersifat material (berwujud) dan non material, begitu juga dengan cara atau bentuknya. Klasifikasi ini untuk mempermudah pemahaman. Berikut penjelasan lengkapnya: Tabaruk yang bersifat material (berbentuk benda-benda a. Tunasan (menghabiskan sisa makanan dan minuman Kiai)

Tunasan merupakan sebuah kebiasaan yang dilakukan oleh masyarakat kepada Kiai yang termasuk kedalam bentuk tabarrukan. Tunasan ini merupakan sebuah kebiasaan yang biasanya banyak dilakukan oleh santri yang sengaja menunggu sisa makanan atau minuman Kiai. Para santri ini menyakini bahwa di dalam makanan atau minuman tersebut mengandung sebuah berkah. Segala hal yang berhubungan dengan Kiai masyarakat anggap memiliki berkah.

Masyarakat percaya bahwa dengan menghabiskan makanan atau minumanKiai yang tidak habis akan mendapatkan sebuah berkah dari sang Kiai. Memperoleh berkah dengan cara demikian biasanya dilakukan hingga berebut dan tak jarang akhirnya mereka berbagi agar dapat merasakan semua. ${ }^{20}$ Sebuah nilai plus dari tabbarukan ini adalah mereka diajarkan untuk dapat berbagi, peduli

\footnotetext{
${ }^{20}$ Hasil wawancara dengan J (santri yang telah mondok selama 7 tahun dan mengabdi selama 3 tahun),tanggal 04-02-2018, pukul 15.45 bertempat di ponpes Darussalam
} 
kepada sesamanya, dan dapat lebih menghargai makanan.

Padahal, apabila hal tersebut dirasionalisasikan, menghabiskan makanan dan minuman Kiai mungkin untuk menghindari mubadzir dan dari menghidari kemubadziran. Berbagi dengan sesama itulah mungkin Allah menurunkan keberkahan berupa kebersamaan dan kebahagiaan. Karena dari hal kecil itu saja mereka dapat merasa bahagia dan semakin percaya bahwa itu adalah berkah dari sang Kiai.

b. Tafaul

Tafaul merupakan sebuah tradisi yang ada di masyarakat berupa meminta nama kepada Kiai untuk anaknya. Nama adalah sebuah doa, harapan orang tua dengan memberikan nama yang indah untuk anaknya, ialah agar kelak anaknya juga memiliki sifat yang sama dengan arti namanya.

Nama-nama yang berasal dari bahasa Arab, atau biasa masyarakat sebut dengan bahasa al-Qur'an menjadi favorit tersendiri, walau terkadang masyarakat sendiri tidak mengetahui apa arti nama tersebut. Tetapi, memberikan nama anaknya dengan nama dari bahasa al-Qur'an menjadi kebanggaan tersendiri bagi masyarakat.

Selain kegemaran masyarakat dalam memberi nama menggunakan bahasa Arab,dalam hal memberikan nama ini juga masyarakat biasanya meminta kepada Kiai untuk memberikan nama anaknya, karena masyarakat percaya bahwa nama yang diberikan oleh sang Kiai, bukan hanya memiliki arti yang indah, tapi juga terdapat doa dan berkah di dalamnya.

c. Catoh

Catoh merupakan sebuah tradisi masyarakat pesantren yang baru melahirkan seorang anak meminta agar anaknya diberkahi oleh Kiai, dengan cara sang anak akan di doakan kemudian kening sang bayi diolesi dengan madu atau kurma oleh orang yang shaleh.

Menariknya, dulu catoh itu dilakukan dengan cara Kiai meludahi mulut sang anak, dan tradisi ini dilakukan atas permintaan masyarakat sendiri. ${ }^{21}$ Meski hal tersebut terkesan tidak lazim, namun catoh menjadi bukti bahwa masyarakat pesantren

\footnotetext{
${ }^{21}$ Hasil wawancara dengan Kang Ade (tokoh agama, sekaligus pengasuh salah satu pondok pesantren yang ada di Buntet), tanggal 27 Juli 18 , pukul 19.35 bertempat dikediamannya
} 
sangat percaya pada berkah. Sebagai salah satu bentuk tabarrukan, catoh menjadi contoh nyatanya.

Tradisi catoh telah membuktikan bahwa pada zamaannya, tradisi ini memiliki banyak peminat.Bahkan, masyarakat pesantren meyakini betul bahwa ada berkah di balik proses meludahi. Disini terbukti bahwa masyarakat mampu melawan bahkan menghilangkan rasa jijiknya demi berkah.

Dari segi medis sendiri, belum diketahui sebenarnya adakah pengaruhnya bagi sang anak, dan bagaimana kehigienisannya bagi kesehatan sang anak. Akan tetapi, faktanya anak yang pernah di catoh sehat dan tidak pernah mengalami atau memiliki riwayat penyakit yang diakibatkan dari tradisi ini.

d. Meminta Air Doa

$$
\text { Pada tradisi masyarakat }
$$
pesantren, ada kebiasaan unik yang sampai saat ini masih ada, yaitu meminta air doa kepada Kiai. Adapun tujuan dari meminta air doa itu bermacam-macam, mulai dari meminta doa untuk kesembuhan anaknya yang sedang sakit, meminta doa untuk anaknya yang hendak ujian hingga meminta doa untuk anaknya agar tidak bandel, idep, dan pintar dalam segala hal.

Kepercayaan masyarakat dalam meminta air tersebut memang beragam, tergantung dengan kebutuhan dan tujuannya masingmasing. Sampai saat ini tidak sedikit masyarakat yang masih melakukan hal tersebut. Bahkan ada juga masyarakat yang hendak pindah rumah,dan anaknya selalu rewel jika di tempat baru, kemudian ia meminta air dan membawa tanah dari sini yang gunanya agar anaknya betah ditempat yang baru, layaknya di tempat yang lama.

Sedangkan bentuk tabarrukan yang bersifat non material diantaranya adalah sebagai berikut:

a. Mengabdi

Mengabdi merupakan salah satu bentuk dari tabarrukan yang sampai saat ini masih banyak dilakukan oleh masyarakat pesantren. Bentuk tabarrukan ini merupakan sebuah tindakan yang dilakukan semata-mata untuk membantu pesantren atau kepentingan Kiai (khidmat).

Dalam hal ini, masyarakat pesantren yang tertarik untuk tetap 
mengabdi biasanya, karena sebuah sugesti yang telah tertanam bahwa dengan mengabdilah ia merasa dapat lebih dekat, dan banyak menemukan sesuatu hal yang sebelumnya belum pernah ia temukan, seperti ketenangan batin hingga kecukupan materi. Padahal apabila dilihat, sesuatu yang didapat dari mengabdi tidaklah membuahkan hasil dari sisi materi (uang) yang banyak, karena sifatnyapun atas dasar kemauan sendiri. Jadi sifat dari yang mengabdi di pesantren ini adalah insidensial bukan continue. $^{22}$

Masyarakat yang mengabdikan dirinya di pesantren entah menjadi tukang masak, tukang kebun, ataupun tukang cuci, tetap bertahan bekerja

karena mengharapkan berkah dari para Kiai. Berkah merupakan sesuatu yang sifatnya non material, yaitu berupa kedamaian, ketentraman dan kecukupan hidup. Berkah selalu dicari dalam hidup orang Jawa, karena hal tersebut berarti ada pengaruh syafaat yang akan

\footnotetext{
${ }^{22}$ Hasil wawancara dengan Kang Ade (tokoh agama, sekaligus pengasuh salah satu pondok pesantren Buntet), tanggal 27 Juli 18, pukul 19.35 bertempat dikediamannya
}

menuntun manusia untuk hidup tenang, kecukupan dan selamat. ${ }^{23}$

Selain mendapat ketenangan hidup, masyarakat juga percaya bahwa hidup dekat dengan Kiai dan mengabdi kepada Kiai, tidak akan membuat hidupnya kekurangan sesuatu hal apapun, bahkan yang ada hidupnya akan lebih terasa berarti, sebab hidupnya selalu diberkahi oleh Kiai. Hidup dekat dengan sosok seorang Kiai merupakan sebuah kebahagiaan tersendiri, karena dengan itulah masyarakat merasa dapat lebih dekat dengan sang kuasa dan dapat lebih memaknai hidup. ${ }^{24}$

b. Mengaji

Mengaji merupakan sebuah aktivitas keagamaan (ritual keagamaan) sehari-hari yang biasa dilakukan oleh masyarakat. Di pesantren sendiri, mengaji biasanya memiliki jadwal masing-masing, baik dalam membahas atau mengkaji sebuah kitab maupun al-Qur'an. Pengajian al-Qur'an sendiri biasanya dilakukan setelah selesai shalat

\footnotetext{
${ }^{23}$ Sabekti Hamid, 'Makna Hidup Abdi Dalem Punakawan Keraton Yogyakarta",Salatiga:Skripsi Universitas Kristen Satya Wacana,2014,hlm. 1

${ }^{24}$ Hasil wawancara dengan R (masyarakat yang telah mengabdi di salah satu pondok pesantren selama 20 tahun menjadi tukang masak),tanggal 23-01-18, pukul 16.15 bertempat di kediamannya
} 
maghrib, yang kemudian di lanjutkan dengan pengajian kitab.

Pada tradisi di masyarakat pesantren sendiri ada istilah ngaji kalong, yaitu masyarakat sekitar yang tidak mondok tetapi ikut mengaji di pesantren. Ngaji kalong adalah salah satu media untuk meminta berkah dari Kiai. Masyarakat juga sudah lumrah dan biasa menitipkan anaknya yang ikut mengaji di pondok kepada Kiai, baik ngaji al-qur'an maupun kitab karangan para ulama seperti nahwu, shorof dan lain sebagainya.

Selain menjadi salah satu media untuk meminta berkah, mengaji juga merupakan sebuah media interaksi antar Kiai dengan masyarakat, baik dengan orang tua maupun dengan anaknya. Orang tua biasanya menggunakan cara menitipkan anaknya kepada Kiai. Melalui hal tersebut secara tidak langsung telah menjalin sebuah kedekatan yang lebih, karena orang tua menjadi lebih sering silaturahim kepada Kiai dan menanyakan bagaimana perkembangan anaknya. Bagi santri, mengaji adalah sebuah kewaiban yang harus dilakkan setiap harinya, akan tetapi selain kewajiban, mengaji juga dijadikan sebagai media untuk meminta berkah dari sang Kiai (mursyid).

c. Mencium Tangan Kiai

Mencium tangan, merupakan salah satu bentuk penghormatan atau rasa hormat seseorang terhadap orang yang dihormatinya. Bentuk rasa hormat ini bisa dilakukan kepada orang tua, guru, ataupun aparat. Adapun teknik mencium tangan atau bersalaman sendiri menurut Islam ialah diawali dengan ucapan salam kemudian mengulurkan tangan kanannya disertai dengan senyuman dan wajah yang berseri. ${ }^{25}$

Pada masyarakat pesantren sendiri cara mencium tangan itu terbagi menjadi dua, yaitu pertama hanya mencium bagian atas tangan dan kedua mencium bagian atas dan telapak tangan. Model atau cara mencium tangan ini sudah ada sejak dulu dan setiap orang mempraktikannya berbeda-beda, sesuai dengan keyakinannya masingmasing. Akan tetapi, di masyarakat Pesantren Buntet sendiri cara mencium tangan yang pertama lebih

\footnotetext{
${ }^{25}$ Djoko Hartono dan Asmaul Lutfauziah, $N U$ dan ASWAJA: Menelusuri Tradisi Keagamaan Masyarakat Nahdiyin di Indonesia, Surabaya: Ponpes Jagad 'Alimussirry,2012,hlm.115
} 
banyak di gunakan. Sedangkan cara yang kedua mulai jarang dipraktikan.

\section{Dinamika Tabarrukan}

Secara umum, masyarakat di Desa Mertapada Kulon termasuk kedalam masyarakat yang berkelompok dan memiliki sistem stratifikasi, yang terbagi kedalam kelompok yang memiliki trah. Trah berasal dari kelompok atau golongan yang masih memiliki keturunan Kiai. Kemudian, kelompok selanjutnya yakni kelompok yang memiliki jabatan, masyarakat yang mempunyai stratifikasi dalam bentuk jabatan yang peroleh dari hasil kerja atau hasil keringat dan usahanya sendiri bukan dari hasil keturunan. Yang terakhir yakni ada kelompok biasa yang berasal dari bawah dan kelompok santri atau pendatang yang menikah dan menetap di desa tersebut (magersari) kelompok ini yang menjadi pelengkap dalam sistem masyarakat di kelompok atau startifikasi yang diatas.

Seiring berjalannya waktu, sistem stratifikasi yang ada perlahan mulai memudar. Baik dari pengaruh luar masyarakat yaitu budaya yang di bawa pada saat masyarakat merantau, baik merantau dalam mencari pengasilan atau kerja maupun merantau dalam mencari ilmu. Pengkelompokan yang kini ada di masyarakat perlahan mulai tersamarkan dan seakan cenderung terlihat sama, tingkat perekomonian maupun keilmuan. Proses diferensiasi yang ada di masyarakat berlangsung seiring dengan berubahnya zaman dan kemajuan pola pikir masyarakat yang semakin berkembang. Walau begitu, tetap saja untuk masalah keturunan tidak dapat disamarkan, karena hal itu bukanlah hasil dari usaha atau kerja keras, melainkan hasil turun temurun.

Tabarrukan yang secara tidak langsung telah menjadi sebuah penghubung antara kelompok masyarakat satu dengan lainnya juga telah mengalami perubahan, baik itu dari kelompok santri ke Kiai maupun dari kelompok masyarakat ke Kiai. Seiring dengan perkembangan pesantren di wilayah Mertapada Kulon yang semakin maju, pemahaman mengenai hal tersebut mulai mengalami perkembangan. Meski tidak berlangsung tetap, adanya perbedaan pemahaman mengenai tabarrukan ini menjadi bukti bahwa dalam kurun waktu tertentu, tabarrukan tidak selalu sama. 
Sepuluh tahun terakhir misalnya, tabarrukan ini berlangsung dengan sangat hikmat. Dimana dalam setiap kesempatan, seorang santri, murid atau masyarakat pesantren pada umumnya akan sangat hormat sekali pada Kiai. Mereka tak segan untuk mencium tangan Kiainya sebagai tanda penghormatan atau bertabarruk pada Kiai.

\section{Tabarrukan merupakan} sebuah bentuk praktik sosial yang dibungkus dengan nilai-nilai keagamaan. Bentuk tabarrukan sendiri tidak jauh dari kegiatan sehari-hari masyarakat pesantren, seperti bekerja, mengaji, silaturahim , dan lain sebagainya. Meskipun tidak semua bentuk tabarrukan adalah kegiatan sehari-hari masyarakat pesantren seperti catoh, tunasan, dan lain sebagainya, tetapi bentuk-bentuk praktik tersebut sudah melekat dan sudah biasa terjadi seperti sudah menjadi kegiatannya sehari-hari bagi masyarakat pesantren.

Meski kebiasaan ini masih ditemukan di kalangan pesantren, namun kesakralan dari tabarrukan model seperti ini perlahan mulai luntur. Hal ini disebabkan oleh pengaruh dari dalam maupun luar diri masyarakat, pengaruh dari luar seperti kebudayan modern yang terus berkembang yang pada akhirnya membentuk norma baru. Bertabarruk tidak lagi dilakukan secara fisik, melainkan juga bisa dilakukan secara non fisik, seperti mengirim do'a yang ditujukkan kepada Kiai atau mursyid, memberikan nama anaknya seperti nama Kiai dengan harapan agar kelak anaknya dapat bersifat sama dengan sang Kiai. Sedangkan pengaruh dari dalam seperti kesadaran masyarakat akan hubungan interaksi antara masyarakat dan Kiai yang semakin berkurang dengan gencarnya media sosial.

Perubahan yang terjadi di masyarakat juga sebenarnya dipengaruhi oleh semakin banyaknya santri yang datang dari berbagai daerah dan membawa pengaruh budaya serta gaya hidupnya. Perubahan-perubahan yang terjadi dalam diri santri maupun masyarakat sebenarnya lazim adanya, karena tuntutan zaman yang memaksanya untuk merubah pola pikir yang mungkin sifatnya masih kolot.

Perubahan yang ada dalam diri santri dan masyarakat tidak hanya berdampak pada hubungan antara 
masyarakat, santri dan Kiai saja, akan tetapi juga berdampak dan mempengaruhi kepercayaan masyarakat terhadap tabarrukan yang dulu dipegang erat dan sangat kuat kaitannya dengan kehidupan masyarakat di pesantren.

\section{Tabarrukan merupakan}

sebuah bentuk kegiatan sosial yang banyak dilakukan oleh masyarakat. Dalam bahasa Weber, tabarrukan disebut sebagai tindakan sosial. Sesuatu yang dapat dikatakan sebagai tindakan sosial ialah tindakan yang apabila terjadi pada manusia atau individu, kemudian ia melekatkan makna-makna yang sifatnya subjektif pada tindakan yang mereka lakukan.

Dalam hal ini, sama dengan tabarrukan yang dilakukan oleh masyarakat pesantren di Desa Mertapada Kulon. Disini, masyarakat pesantren melekatkan makna-makna yang terdapat dalam tabarrukan yang dilakukannya, entah makna tersebut masih bersifat sakral atau tidak, yang jelas masyarakat yang memaknai tindakan yang ia lakukan sendiri. Misalnya masyarakat percaya bahwa hanya dengan menghabiskan makanan atau minuman sisa Kiai (tunasan) ia akan memperoleh berkah dari seorang Kiai. Perilaku yang masyarakat lakukan, adalah menghabiskan makanan atau minuman, kemudian masyarakat melakuan sebuah tindakan dengan memberikan makna yang bersifat subjektif berupa adanya berkah di dalam makanan dan minuman yang telah dimakan atau diminum oleh sang Kiai. Pemaknaan itulah yang disebut oleh Weber sebagai tindakan sosial.

\section{Korelasi Konsep Kharisma dalam Tabarrukan di Pesantren}

Dalam hal ini, Weber juga memperkenalkan sebuah metode yang digunakan untuk mempelajari sosiologi dengan istilah verstehen, yaitu sebuah metode yang digunakan untuk memahami tindakan manusia melalui pemahaman subjektif individu. ${ }^{26}$ Weber berasumsi bahwa seseorang dalam bertindak tidak hanya melaksanakan, tetapi juga menempatkan diri dalam lingkungan berpikir dan prilaku orang lain. Hal ini sama dengan tabarrukan, seseorang yang melakukan praktik tersebut tidak hanya melaksanakan,

\footnotetext{
${ }^{26}$ Wirawan, Teori-teori Sosial dalam Tiga Paradigma, Jakarta: Kencana, 2012,hlm.105
} 
tetapi ia juga menempatkan diri dengan prilaku orang yang ia mintai berkah.

Konsep tindakan dan
pendekatan yang dilakukan
masyarakat ini sebetulnya lebih
mengarah pada suatu tindakan yang
bermotif pada tujuannya yang hendak
di capai yaitu memperoleh berkah
dari sang Kiai. Seperti yang
diungkapkan oleh Weber bahwa
menurutnya yang dipelajari oleh
sosiologi adalah tindakan sosial,
tindakan manusia disebut sebagai
tindakan sosial ketika memiliki arti
atau diartikan secara subjektif oleh
aktornya dan tindakan tersebut
dihubungkan juga dengan tingkah
laku orang lain.

Dalam teori ini Weber menggunakan metodologinya untuk menjelaskan makna tindakan dengan memperkenalkan empat tipologi dasar tindakan yaitu tindakan rasionalitas instrumental, rasionalitas alat-tujuan, tindakan tradisional dan tindakan efektif. Mengenai empat tipologi dasar tindakan ini, yang paling penting yaitu pembedaan Weber diantara dua tipe tindakan rasional.

Pertama rasionalitas instrumental atau nilai yaitu tindakan yang dilandaskan oleh sebuah kepercayaan yang sadar akan adanya nilai itu sendiri, suatu bentuk perilaku religius, etis, estetis atau bentuk lainnya terlepas dari prospek itu berhasil atau tidak. Sama halnya dengan masyarakat yang melakukan tabarrukan, ia tabarrukan atas dasar kepercayaan yang terwujud dalam bentuk tindakan seperti tunasan, catoh, meminta air doa, tafaul, mengabdi bekerja di pesantren, mencium tangan dan bentuk lainnya yang terlepas dari pikiran ia akan berhasil mendapatkan berkah dari seorang Kiai atau tidak.

Kedua rasionalitas tujuan-alat yaitu sebuah tindakan yang dilandaskan oleh pengharapanpengharapan mengenai perilaku objek di dalam lingkungan dan perilaku manusia lainnya. Pengharapanpengharapan tersebut digunakan sebagai sebuah alat atau kondisi untuk mencapai suatu tujuan dari pelaku dan tindakan tersebut tentunya telah dipertimbangkan secara rasional agar ia dapat mencapai tujuan itu.

Dengan kata lain, ia telah menilai dan menentukan tujuan itu dan bisa saja tindakan itu dijadikan sebagai cara untuk mencapai tujuan 
lain.Misalnya seperti seorang Kiai yang memperlakukan orang yang mengabdikan dirinya dipesantren dengan baik, halus dan santun dengan harapan akan memperoleh kesetiaan. Pengharapan akan memperoleh sebuah kesetiaan itu digunakan sebagai alat untuk mencapai tujuannya yaitu mendapatkan kesetiaan dan tindakannya tentu telah dipertimbangkan secara rasional.

Ketiga tindakan tradisional yang jauh lebih banyak diperhatikan oleh Weber, yaitu sebuah tindakan yang ditentukan oleh cara berperilaku individu yang biasa dan sudah lazim. Keempat tindakan efektif yaitu tindakan yang ditentukan oleh keadaan emosional individu, tindakan ini tidak banyak diperhatikan oleh Weber.

Seorang Kiai di mata
masyarakat merupakan sosok yang
mulia, dikagumi, dan diistimewakan
karena memiliki wibawa dan
kharisma. Weber mendefinisikan
bahwa kharisma sebagai suatu sifat
tertentu dari suatu kepribadian
seorang individu berdasarkan
pengakuan orang lain yang
menganggap ia luar biasa dan
diperlukan sebagai orang yang
memiliki sifat-sifat ghaib, supranatural, sifat unggul atau paling sedikit dengan kekuatan yang khas dan luar biasa. Sama seperti Kiai yang memiliki sifat arif, berwibawa dan itu berdasarkan atas pengakuan masyarakat yang menganggapnya luar biasa, memiliki sesuatu yang tidak dimiliki orang lain, ia dapat menyembuhkan orang hanya dengan air doa. Kiai dianggap sebagai seorang pahlawan yang memiliki kekuatan supranatural yang dapat menyembuhkan.

Masyarakat percaya bahwa Kiai adalah sosok manusia yang diciptakan sebagai wakil tuhan, ia suci dan memiliki sesuatu yang tidak dimiliki manusia pada umumnya. Seperti yang diungkapkan oleh AN bahwa:

"Saya meyakini bahwa Kiai adalah orang tua kedua yah setelah orang tua yang melahirkan saya. Kiai selalu mendoakan dan memberikan petuah yang luar biasa yang dapat mendatangkan berkah. Berkah disini artinya tambahnya kebaikan dari yang sebelumnya tidak tau menjadi tau dan ketika saya didekat Kiai, saya merasa menjadi lebih baik walaupun masih dalam proses, semakin kita dekat dengan Kiai, semakin dekat juga kita kepada Allah, karena apa yang datangnya dari Kiai pasti ada sesuatu hal penting yang harus disampaikan, karena Kiai adalah orang yang mengimplementasikan apa yang datang dari Allah, keberkahan lahir karena dekat dengan Allah dan 
karena Kiai yang paling takut kepada Allah innama yahsyallohu biibadihilulama artinya, Kiai berusaha mengemban amanah dari Allah karena akan mendidik bukan hanya jasmaninya akan tetapi juga batiniah" 27

Kharisma merupakan sebuah pengakuan terhadap suatu tuntunan sosial. Dalam konteks lain juga, Weber mengartikan kharisma sebagai sifat yang melekat pada diri seorang pemimpin seperti yang telah dijelaskan diatas, dan dengan adanya sebuah pengakuan dengan penyebutan pemimpin kharismatik membuat seorang individu seolaholah diberi tugas khusus oleh Tuhan, karena telah diberi karunia lebih oleh tuhan sebagai bekal untuk memimpin sekelompok manusia.

Dari temuan dan analisis yang telah penulis paparkan diatas ini sesuai dengan pemikiran konsep kharisma Weber. Dalam pemaparan tersebut telah dideskripsikan bagaimana tabarrukan yang di sebut Weber sebagai tindakan sosial dan tiga tipe otoritas yang dapat menggambarkan posisi otoritas Kiai. Kharisma Kiai diakui oleh masyarakat dan masyarakat yang

\footnotetext{
${ }^{27}$ Hasil wawancara dengan AN(santri sekaligus pengurus di salah sau pondok pesantren yang telah mondok selama 10 tahun), tanggal 7-08-18, bertempat di LKM
}

mengakui itu secara spontan akan segan,mengistimewakan dan memuliakannya dalam bentuk praktik sosial, seperti interaksi dan memberikan sebuah penghormatan yang berbeda. Hal tersebut terjadi karena Kiai memiliki wibawa tersendiri yang dapat memikat masyarakat untuk bersikap segan dan hormat terhadapnya. Walaupun begitu, kharisma yang ada dalam diri seorang Kiai terkadang tidak bersifat tetap atau sementara, karena faktor tertentu kharisma itu dapat hilang dari dirinya.

Dalam konteks tabarrukan, perubahan juga terjadi di lingkungan Pesantren Buntet. Banyak hal yang membuat perubahan ini muncul secara dinamis dan terbilang sulit dibendung, yaitu seperti dampak dari pembangunan asrama besar, tabarrukan di Pesantren Buntet semakin gencar dilakukan perkiraan pada tahun 198, pada saat itu santri di ungsikan ke rumah-rumah kiai. Lambat laun setelah semakin berkembangnya dunia modern dan sistem pembelajaran yang berjalan di masing-masing rumah Kiai, perubahan semakin terasa. Awal mula perkembangan Pesantren Buntet, dari mulai pembangunan hingga tipe 
pondok pesantren dari salaf ke semi modern, terlihat pada masa kepemimpinan Kiai Abdul Jamil tahun 1842-1919. Penerus Kiai Mutta'ad ini bekerja keras untuk dapat memajukan pesantren baik dalam bidang pengelolaan maupun dalam aspek akademis. Untuk memaksimalkan hal tersebut, beliau merekrut semua Kiai yang kebanyakan masih keluarga dan santri-santri senior untuk aktif memajukan pesantren. Gedunggedung baru dan sebuah masjid besar mulai didirikan untuk mengakomodasi jumlah santri.

Perjalanan pesantren dari tahun ke tahun semakin pesat dan pertumbuhan penduduk juga semakin banyak. Berawal dari situlah tepatnya sekitar tahun 1990-2000 perubahan mulai terlihat, baik dalam diri santri maupun dalam diri masyarakat sekitar. Mulai dari perubahan kecil dalam diri santri, dulu santri sangat manut dan patuh pada setiap aturan yang ada dalam pesantren, baik aturan yang tertulis maupun yang tidak tertulis. Sekarang tidak sedikit santri yang melanggar aturan-aturan yang sudah ada di pesantren. Kemudian perubahan mulai terlihat pada tahun
2000 dan semakin mencolok sekitar tahun 2006.

Perubahan tersebut terlihat dari seluruh sisi lapisan masyarakat, baik santri, masyarakat hingga kiai. Bentuk-bentuk tabarrukan lain seperti catoh, tunasan dan tafaul juga sudah mulai berkurang. Kini masyarakat lebih senang memberikan nama anaknya sendiri yang kadang disamakan dengan nama seorang selebritis, atau aktof film baik dalam maupun luar negeri favorit orang tuanya. Entah masyarakat mengetahui atau paham tidak dengan artinya, yang pasti ia merasa bahwa nama anaknya itu keren dan tidak jadul (jaman dulu).

Perubahan paling mencolok yang terjadi pada masyarakat, ialah pernikahan dengan orang luar pesantren yang memang memiliki budaya, adat dan kebiasaan yang berbeda dengan kehidupan masyarakat pesantren. Selain itu, bertambahnya jumlah penduduk juga merupakan salah satu faktor perubahan yang ada di masyarakat. Dengan jumlah penduduk yang semakin banyak, pernikahan dengan orang luar yang mengakibatkan budaya luar semakin banyak masuk 
dan seakan mendominasi juga salah satu hal yang akhirnya mengikis budaya pesantren, ditambah lagi kesandaran dari masyarakat akan pendidikan agama juga mulai berkurang. Dulu para orang tua tidak segan untuk memarahi bahkan mungkin memukul atau mencubit anaknya jika tidak berangkat mengaji. Sedangkan saat ini, orang tua terlihat sedikit acuh, anaknya dibiarkan menonton TV atau bermain ponsel ketimbang untuk menyuruhnya mengaji.

Perubahan-perubahan yang ada di masyarakat bukan hanya terjadi dalam diri santri dan masyarakat sekitar pesantren saja, tetapi perubahan juga terjadi pada Kiai. Kesibukan para Kiai yang padat membuat interaksinya dengan masyarakat menjadi sangat terbatas. Pendekatan Kiai pada masyarakat kini dan dulu juga berbeda. Dulu Kiai berbaur, turun ke masyarakat. Selain itu, kini sikap masyarakat juga cenderung lebih memilih dalam posisi aman, asalkan bisa untuk makan saja cukup. Jika tidak bekerja di pondok, pemuda-pemudinya pergi merantau, jarang ada yang benar-benar merintis usaha di pesantren. Peluang usaha di pesantren justru dilihat dan diambil oleh masyarakat luar pesantren. ${ }^{28}$

Saat ini, Kiai mungkin lebih banyak melakukan interaksi sosial pada saat disekolahan, dan pada saat di luar lingkungan sekolah Kiai lebih disibukkan dengan urusan atau hal yang ada di pondok pesantren. Sedangkan menurut masyarakat sendiri, perubahan Kiai selain dapat dilihat dari semakin kurangnya kontak langsung dengan masyarakat karena kesibukan pesantren juga Kiai saat ini berubah mengikuti perkembangan zaman sehingga banyak sebutan Kiai gaul.

\section{SIMPULAN}

Dari hasil penelitian yang telah disampaikan, dapat dikemukakan kesimpulan bahwa Tradisi tabarrukan ini merupakan sebuah tradisi yang selain digunakan oleh masyarakat untuk meminta berkah Kiai, juga dijadikan sebagai sebuah alat komunikasi masyarakat untuk dapat dekat dengan Kiai, begitupun sebaliknya, dengan tabarrukan Kiai

\footnotetext{
${ }^{28}$ Hasil wawancara dengan AN (santri, sekaligus pengurus di salah satu pondok pesantren, telah mondok selama 10 tahun), tanggal 07-08-18, bertempat di LKM Buntet
} 
juga dapat menjalin komunikasi dengan masyarakat.

Tabarrukan secara umum terbagi menjadi dua jenis, yaitu tabarrukan yang bersifat secara material atau berwujud dan tabarrukan yang bersifat secara non material. Tabarrukan yang bersifat secara material ini seperti menghabiskan sisa makanan dan minuman Kiai (tunasan), meminta nama (tafaul), meminta air doa, catoh, dan lain sebagainya. Sedangkan tabarrukan secara non material dapat berbentuk seperti pengabdian (khidmat), mencium tangan Kiai, mengaji, silaturahmi (sowan), dan lain sebagainya.

Bentuk-bentuk praktik sosial diatas tidak hanya diartikan sebatas kegiatan sehari-hari yang biasa dilakukan oleh masyarakat terhadap Kiai. Tetapi, lebih dari itu, masyarakat pesantren memberikan sebuah makna yang cukup dalam, yang terdapat dalam setiap bentuk praktik social tersebut. Masyarakat pesantren juga telah menganggap tradisi tabarrukan sebagai salah satu ritual peribadatan yang dapat mendekatkan dirinya dengan Sang Pencipta.
Seiring berjalannya waktu, tradisi tabarrukan yang ada di masyarakat pesantren mulai mengalami perubahan. Ada banyak factor penyebab terjadinya perubahan, seperti perkembangan zaman semakin maju, dunia teknologi yang semakin canggih, masukkan budaya baru yang tidak dapat dibendung oleh masyarakat, dan lain sebagainya. Mulai tahun 1990 hingga tahun 2006 saja perubahan itu sudah dapat terlihat dengan jelas, baik perubahan dalam diri santri, Kiai, maupun perubahan dari dalam diri masyarakat sendiri.

\section{DAFTAR PUSTAKA}

A Gari. Y. (1998). Kepemimpinan dalam Orientasi. Jakarta: Prenhalindo.

A Pius. P. \& Al-Barry, M.D. (1994). Kamus Ilmiah Populer. Surabaya: Arkola.

Abdullah, A. (2005). Sosiologi Islam. Bogor: IPB Press.

Anthony, G. (1985). Kapitalisme dan Teori Sosial Modern. terj. Soehaba Kramadibarta.Jakarta: UI Press.

Departemen Pendidikan dan Kebudayaan. (1989). Kamus Besar Bahasa Indonesia. Jakarta: Balai pustaka.

F Thomas.Q. (1987). Sosiologi Agama. jakarta: CV Rajawali.

Haedari Amin.et al. (2004). Masa Depan Pesantren. Jakarta: IRD Press. 
Hakim Lutfi. (2007). Berkah Kiai dalam Pandangan Santri. Skripsi: STAIN Salatiga.

Hamid Sabekti. (2014)."Makna Hidup Abdi Dalem Punakawan Keraton Yogyakarta".Salatiga:Skripsi Universitas Kristen Satya Wacana.

Hardiman Budi. (2003). Melampaui Positifisme dan Modernitas. Yogyakarta: Kanisius.

Hartono Djoko dan Asmaul Lutfauziah. (2012). NU dan ASWAJA: Menelusuri Tradisi Keagamaan Masyarakat Nahdiyin di Indonesia. Surabaya: Ponpes Jagad 'Alimussirry..

Huda Nor. (2015). Sejarah Sosial Intelektual Islam di Indonesia. Jakarta: PT Raja Grafindo Persada.

Idrus Muhammad Ramli. (2010). Buku Pintar Debat dengan Wahabi. Surabaya:Bina Aswaja.

Ishomudin. (2002). Pengantar Sosiologi Agama. Jakarta: Chalia Indonesia.

Ismail Faisal. (1999). NU Gusdurisme dan Politik Kiai. Yogyakarta: Tiara Wacana Yogya.

Lauter H Robert. (1993). Perspektif Perubahan Sosial. Jakarta: PT. Rineka Cipta.

Nashir Al-Judai bin Abdurrahman bin Muhammad. (2009). Tabarruk: Memburu Berkah Sepanjang Masa di Seluruh Tempat di Dunia Menurut Al-Qur'an dan As-Sunnah.Jakarta: Pustaka Imam Syafi'i.

Qomar Mujamil. (ny). Pesantren dan Transformasi Metodologi Menuju Demokrasi Institusi. Jakarta:Erlangga.
Rebiru J. (1992). Dasar-dasar Kepemimpinan. Jakarta: CV. Pedoman Ilmu Jaya.

S Bryan. Tuner. (1994). Sosiologi Islam: Suatu Telaah Analisis Atas Tesa Sosiologi Weber. ter. G. A. Ticoalu.Jakarta: Raja Grafindo Persada.

Sa'diyah Cholilatus. (2015). Pemaknaan Berkah Dalam Pengabdian Santri di Pondok Pesantren Nurul Huda Dusun Suci Desa Jubellor Kecamatan Sugio Kabupaten Lamonga. Surabaya: Skripsi UIN Sunan Ampel Surabaya.

Soekanto Soerjono dan Budi Sulistyowati. (2014). Sosiologi Suatu Pengantar. Jakarta: PT Raja Grafindo Persada.

Syam Nur. (2005). Islam Pesisir. Yogyakarta: LkiS Pelangi Aksara.

Usman Ali. (2013). Kiai Mengaji Santri Acungkan Jempol. Yogyakarta: Pustaka Pesantren.

Weber Max. (2012). Sosiologi Agama.Yogyakarta: IRCiSoD.

Wirawan. (2012). Teori-teori Sosial dalam Tiga Paradigma. Jakarta: Kencana.

Woodward Mark. (1999). Islam Jawa: Kesalehan Normatif Versus Kebatinan. Penerjemah Hairus Salim. Yogyakarta:LkiS.

Zamakhsyari, D. (1982). Tradisi Pesantren Studi Tentang Pandangan Hidup Kiai.Jakarta: LP3ES.

Zulfikar, F. (2015). Implikasi Kepemimpinan Transformasional KH. Mufid Mas'ud Terhadap Perilaku Santri di Pondok Pesantren Sunan Pandanaran Yogyakarta.Yogyakarta:Skripsi UIN Sunan Kalijaga. 